\title{
Alphabet Blocks: Expanding Conceptions of Language With/in Poetry
}

As a poet and language educator, I invite and encourage writers to take risks in their writing, to engage innovatively with a wide range of genres, to push boundaries in order to explore creatively how language and discourse are never ossified, but always organic; how language use is integrally and inextricably connected to knowledge, identity, subjectivity, and being in the world. I invite writers, whether English is a first language or an additional language, to know themselves in poetry, to know themselves as poets. We live in a contemporary culture that mostly ignores poetry. This is unfortunate because poetry invites alternative ways of knowing and being and becoming. I encourage all writers to write poetry, because poetry is a capacious genre that opens up endless possibilities for expression and communication. In this essay I offer a series of poems about language, discourse, epistemology, and pedagogy. I hope these poems will invite language educators and scholars from diverse perspectives and experiences to consider how writing poetry stimulates the imagination and inspires the heart to ask questions about our lives and the world we live in.

Poète et enseignant de langues, j'encourage vivement les écrivains de prendre des risques quand ils écrivent, de s'employer de façon innovatrice à connaître toute une gamme de genres, de repousser les frontières - le tout dans une exploration inventive de l'évolution organique et constante de la langue et du discours, et de la façon dont l'emploi de la langue est intégralement et inextricablement lié aux connaissances, à l'identité, à la subjectivité et à notre existence. Je lance l'invitation aux écrivains, que l'anglais soit leur langue maternelle ou pas, de se découvrir à travers la poésie, de se connaître en tant que poètes. La culture dans laquelle nous vivons fait, en grande partie, abstraction de la poésie, ce qui est dommage car la poésie propose des voies alternatives de connaître, d'être et de devenir. J'encourage tous les écrivains à écrire de la poésie car il s'agit là d'un genre qui ouvre la voie à d'innombrables possibilités expressives et communicatives. Dans cet article, je propose une série de poèmes touchant la langue, le discours, l'épistémologie et la pédagogie qui, je l'espère, provoqueront chez les enseignants de langues et les chercheurs de diverses perspectives et ayant différents vécus, une réflexion sur l'écriture de la poésie et les façons dont elle stimule l'imagination et inspire l'âme à se poser des questions sur notre vie et notre monde. 


\section{Opening Rumination}

As a poet and language educator, I teach and mentor many writers. I encourage all of them-writers in elementary and secondary classrooms, writers in undergraduate and graduate programs, and other writers in a diverse network of community life-writing groups that span the generations from young adults to senior citizens-to pay attention to the alphabet and the play(fullness) of language. Above all, I invite writers, whether English is a first language or an additional language, to know themselves in poetry, to know themselves as poets. Hanging over the desk in my office is a poster of the alphabet. The 26 letters, brightly colored and whimsically shaped, remind me that as a poet and a language educator, I work (and play) daily with the alphabet. The letters are the capacious and creative materials of my writing, scholarship, and pedagogy.

As a student in school, I did not feel that I belonged. Instead I learned to play a game in school, a carefully regulated game of obeying the teacher's directions and restrictions. I was convinced that teachers had a series of templates in their heads: the ideal essay, the ideal story, the ideal responses to questions. My task as a student was to imitate that ideal as accurately as I could. I was always trying to please the teacher. In school I never wrote for personal reasons or for fun; I never wrote about any issue or experience that was important to me; I never wrote in order to question or experiment; I never wrote anything in school that I was eager to write. Instead I wrote essays and a few narratives and countless responses to questions as directed by the teachers. After graduating from secondary school, I limped through years of frustrating writing experiences in university classes where I was mostly afraid to write because I was convinced that writing was all about knowing the rules and mastering effective English. Now, as a language educator, I invite and encourage writers to take risks in their writing, to engage innovatively with a wide range of genres, to push boundaries in order to explore creatively how language and discourse are never ossified, but always organic; how language use is integrally and inextricably connected to knowledge, identity, subjectivity, and being in the world.

One of the most moving books I have read recently is Wild Swans: Three Daughters of China by Chang (2003), which narrates the story of three generations in 20th-century China. Chang recounts the stories of her grandmother, her parents, and herself. This memoir demonstrates how the personal is always political and historical, how the personal always constitutes the building blocks of history. The unique, individual, seemingly small stories of people form the shape of historical-social-cultural-political-ideological movements. Like a film where each frame contributes to the simulation of movement and reality, or like a still digital picture that is composed of billions of pixels, the whole is only rendered through the conjunction and creative efficacy of the parts. About China during Mao's rule, Chang de- 
scribes how "the whole nation slid into doublespeak. Words became divorced from reality, responsibility, and people's real thoughts. Lies were told with ease because words had lost their meanings - and had ceased to be taken seriously by others" (p. 225). Chang also notes that during this time, "writing poetry became a highly dangerous occupation" (p. 367).

We live in a contemporary culture that mostly ignores poetry. This is unfortunate because poetry invites alternative ways of knowing and being and becoming. I encourage all writers, whether English is their first language or an additional language, to write poetry, especially because poetry is a capacious genre that opens endless possibilities for expression and communication. It is not my intention to ignore or conflate the differences between writing in English as a first language and writing in English as a second language. There are significant differences that need to be considered when teaching writing with students who use English as their first or additional language. But at the same time, I contend that almost no one knows poetry intimately, regardless of their language experiences. Poetry is mostly ignored in the contemporary world, and few of us experience much confidence when we are invited to write poetry.

So in this essay I offer a series of poems about language, discourse, epistemology, and pedagogy. I hope they will invite language educators, scholars, and writers from diverse perspectives and experiences to consider how writing poetry stimulates the imagination and inspires the heart to ask questions about our lives and the world we live in.

\author{
Poetry \\ slows us down, \\ calls us to play, \\ invites us to listen, \\ opens ways of knowing, \\ provides a site for dwelling.
}

"The language poets use is and is not the language that all of us use. For a poet a word carries in itself an abundance of meanings" (Winterson, 1995, p. 80).

\title{
Alphabet Blocks
}

$\alpha \quad$ I write a lot of words, speak a lot of words, think a lot of words, live a lot of words, and really there is no reason why I should shape the words into poems.

Surely the poet's job is to choose, assess, grade, like a trustworthy butcher. 
I must be ruthless with wordy proliferation.

I can write a lot of words in 3 minutes,

once timed myself, at least 223 words. So,

just imagine how many words I could write

in an hour, a day, a week, a month, a year.

I must be parsimonious! So, I just scratched out the words in my journal, and there will be no poem made with those words, unless, of course, you count this poem about scratching out words and not writing a poem, a dog chasing its tail, the self-reflexive circularity that gets postmodernists in trouble, especially with Terry Eagleton, circling overhead, counting every word.

$\beta \quad$ Because words seek places beyond the alphabet, I write in anticipation I will find the words I need, or the words will find me.

$\chi \quad$ My first memory is dark:

early morning, Lucy

in a purple dress swung

me between her legs.

I remember a blank black page

I cannot write on

with India ink. I need light

like rescue ropes

in the maelstrom, vertiginous

with verbs, including $b e$.

$\delta$ I want to know the names of plants, trees, flowers, birds, clouds, but of course I don't and I won't, no end to the knowledge I need to write my poems, except if I waited till I had the knowledge, I would never write a poem, too busy surfing the Internet without end. So, I need to write about what I know and continue to learn more as I go. Nobody knows everything. Agnosticism is part of the humility needed for writing poetry. This summer I learned about rosehips. Why didn't I learn about rosehips when I was growing up. Did the people around me know about rosehips? Did I care to know? Probably not, especially when I needed to learn the names of English kings and queens. Perhaps I live in chaos beyond naming. Perhaps I place too much faith in naming. Is there any need to describe the sky if I am not able to describe it in an unfamiliar way that will help us see its familiarity? Is the sky waiting for me to name it, like another Adam, compelled to acknowledge the ends of language?

$\varepsilon \quad$ A poem is like a butterfly.

Often unwieldy, without

grace, it works hard

to navigate the sturdy wind,

appears suddenly, startles me. 
$\phi \quad$ The difference between a poem and a painting is that the painting hangs on a wall where it can be seen and enjoyed every day, some days many times. A poem gives pleasure in the making and again in the reading, but how many people will read a poem? A painting can give pleasure at least 365 times a year. A poem is glad to give pleasure occasionally, like a cat, penurious with affection.

$\gamma \quad$ What good

is a poem

in an affluent age,

an effluent age,

like ours?

$\eta \quad$ I have lost writing a number of times, especially because of computer meltdown and car theft. On one occasion, the loss of the writing paralysed me for weeks, but on another occasion, the loss opened up a new path for writing. I don't think our writing is ever really lost. There is a law of thermodynamics which claims energy is never lost, only transformed. While my high school physics is decades old, I am thinking a lot these days about energy and ecology and interconnections in the heart's course.

l In my poetry I seek the way, the wisdom for living well in the longing of language to name ourselves where we know our long belonging, and I just told Lana I could spend a whole lifetime working on a single poem because the poem is never finished, only suspended till the return, when, where ever.

$\varphi \quad$ In August, I helped George build a work shed. Day after day we sawed and hammered, put the pieces together, with care, like a big Ikea project. George knew what he was doing. I didn't. I followed him. Like a poet, George was 
conjuring out of imagination

and plans with frequent trips

to Stan Dawe's for more supplies.

And like building a poem,

the process could not

be hurried, needed time.

$\kappa \quad$ The really sad part of infidelity is that

it has nothing to do with the quotidian,

with everyday living. Infidelity is born

out of a mesmerized, confused, hypnotic

state of lostness, of not-being-present.

Infidelity is conjured out of the imagination

that has lost its roots, its mooring in the earth.

It is easy to spell stories with no connection

to others, to the earth, to past and future.

Poetry is the way of fidelity.

$\lambda \quad$ Like the countless beachstones

I can't tell you the stories I have lived in this place, even though I mostly only came here

in the summers and for many years did not come at all, still clutching the wild chaotic world in my words.

$\mu \quad$ I no longer write, at least not much,

like I am scared of writing, frightened

of remembering, eager to live in the present moment, perhaps unable to live well in forgiveness, accept

that the past is always present, always a part of living,

not only a part that holds in the beginning,

that comprises the first sequence of chapters.

Instead, the past is still present. It is still being lived, is still alive, is still living, and I want to proclaim the future does not count, has not yet been lived, and therefore does not enter into my storied universe.

But I believe in the eschaton, the future, the hope.

The future is then like the past, also present.

Perhaps the future is telling the stories that are

possible when we attend to the art and heart

of story-telling. The future is the panoply

of versions of stories that can be told to reveal

the world, not in myths of linear progress, but

as growth to freedom by artful attending to

the momentous moment that is never monotonous.

V Love cannot be defined,

and so poets, craving a challenge,

compose love's meaning, 
by seeking ways into the labyrinth

of nonsense where Cupid shoots

errant arrows, random like

randy rabbits, and laughs

at the limits of law, litters

with reckless abandon

more letters than we can

use in a lifetime.

O In language I calculate the world.

I build intricate equations

with unknowns of $x$ and $y$,

but the answer is not in the back

of the book, so I never know

if I see anything right.

$\pi \quad$ The ecology (and economy) of words:

where do the words go?

So many words spelled out without a spell.

When do words lose their spell?

Imagine yourself wild with words.

$\theta \quad$ Where poets are eager to understand the ineffability of wonder, joy, love, grace, spirit, and the whole host of abstract nouns, I write about the quotidian experiences of backyards, always with a sense of the extraordinary at work in the ordinary, and seek wonder by attending to the inexorable, inevitable experiences of every day, always effing the ineffable.

$\rho \quad$ I fear the truth

in some stories

like a blast furnace

that first singes

the eyebrows and

then incinerates bone.

$\sigma \quad$ Solutions for heart-burn include:

Pepto-Bismal and poetry.

In the tangled midst of memories, the heart is resilient and calls out for a poet's language with the breath of dark moist rum-soaked fruit cake like Lana just made for Christmas. 
Today while I revised this poem, the oil furnace stopped blowing, and Sam the Irving's repairman is on his way, hopefully soon, since on this winter's day in York Harbour, I feel like Bob Cratchit scratching figures in Ebenezer Scrooge's accounts, and as I wait, I don't want to whine, but this poem is failing to keep us warm.

v Textual affairs include: the desire to write, and the desire to be written, in words composing, always coming, always posing, promised pleasure of textuality, unconsummated relations, textual intercourse without climax or end.

$\varpi \quad$ I grow angry with word waste, so much breath for so little wisdom. What happens to words that prattle and rattle with desiccated, disheartened, disembodied whispers like basement dust in a beam of light or ubiquitous flotsam in the world's oceans or discarded satellites in erratic orbit around the earth?

W I am my words;

my words are me.

You are your words; your words are you.

I am your words; your words are me.

You are my words; my words are you.

$\xi \quad$ The language of poetry pushes at edges, sometimes even extending beyond the edges, even to the places where language refuses comprehensibility, clarity, coherence, composition (I love lists, not for the way they organize but for their infinite, endless possibilities).

Some texts refuse consumption, easy access, even a comfortable reading location.

The reader must struggle to locate their positions for responding.

Some texts involve an intricate and complex textualizing that refuses to be still.

Some texts invite me to let the words flow around me, as well as in and through me. 
I must relinquish the desire to hold the text in place, for then I carry the memory of mystery,

even the mystery of my story, to other places, places like e.e. cummings where "I have never travelled."

$\psi \quad$ In this place the sun rises in the harbour, and light and shadow are the alphabet that calls and composes my senses, and I make poems, and find sustaining places of stillness and stability.

$\zeta \quad$ How many dreams do I need to record on paper? I have many dreams that I do not wish to record. It takes wise courage to know when to be silent.

In the end the mime Marcel Marceau alone speaks a word.

$$
\begin{gathered}
\text { Poetry } \\
\text { slows us down, } \\
\text { calls us to play, } \\
\text { invites us to listen, } \\
\text { opens ways of knowing, } \\
\text { provides a site for dwelling. }
\end{gathered}
$$

"Discourses structure both our sense of reality and our notion of our own identity" (Mills, 1997, p. 15).

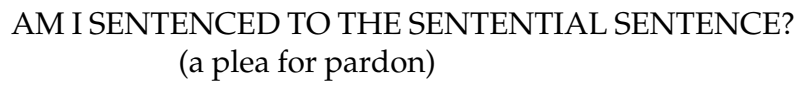

In the sentence

what part

am I?

In the sentence

what do

I do?

simple subject nominative absolute auxiliary nominative of address predicate verb predicate nominative predicate adjective adverbial objective object of preposition indirect object verbal objective predicate adjective objective predicate noun direct object

Am I

the subject

or

the object

of the sentence?
Am I

every part

or

no part

of the sentence? 


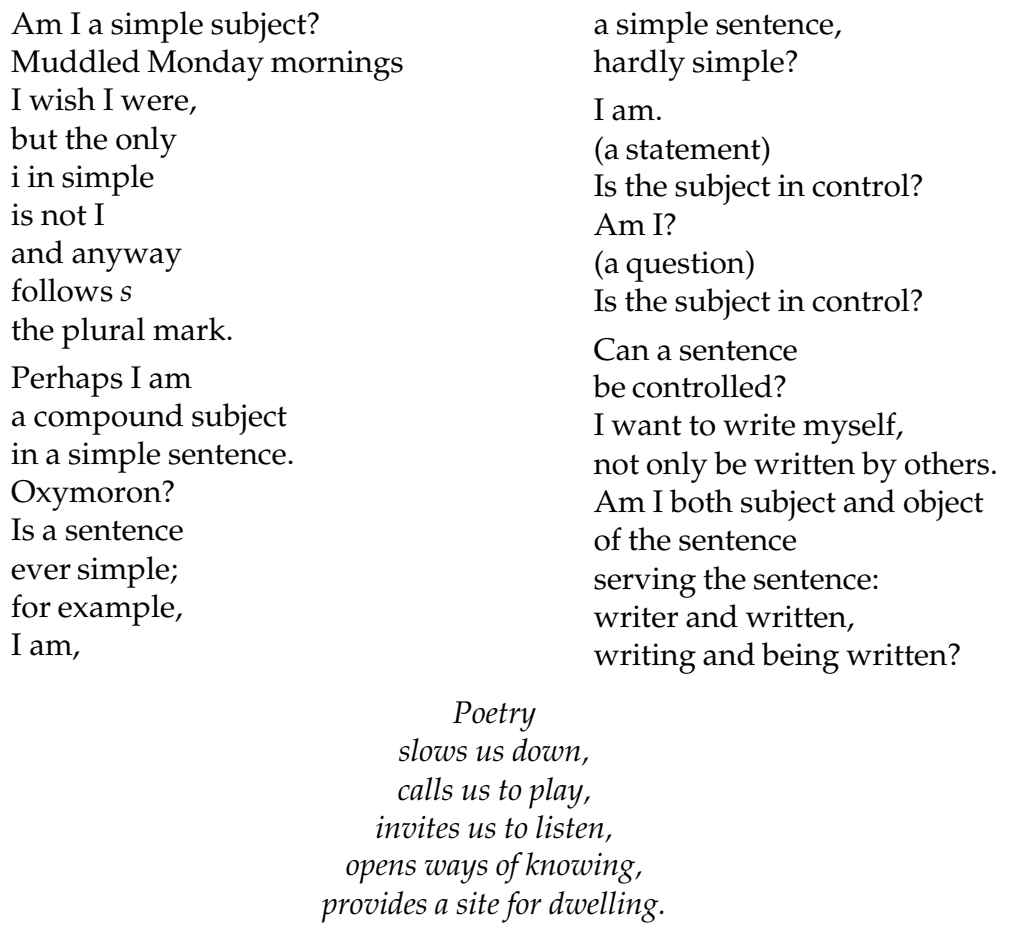

"Poetry does not describe. It is the thing. It is an experience, not the secondhand record of an experience, but the experience itself" (Griffin, 1995, p. 191).

\section{IN THE BEGINNING}

As I shape language, alchemically language shapes me, my poems writing themselves in autobiographical urgency.

Beginnings and endings and all the countless moments between the beginnings and endings that are more beginnings and endings.

Compelling words cannot be commanded, will find their way when they wish, organic chorus.

Do different alphabets divide the world differently, full of desire for divining concealed secrets?

Emphatically, empathetically, energetically evoke experience in language like echolocation.

Fat, flat, flatulent words fill the air in this board room where I am bored with chewing words like myrrh from a fir tree.

Grammar slips through the stipulations of handbooks when nouns and verbs scramble to find their rhythms in gramarye.

How does poetry know? What does poetry know?

How do I know poetry? What do I know? 
Incarnate word, the Word in flesh, embodied presence, poems born in the imagined present.

Journeys begin somewhere, but navigating the landscape requires a map, compass, GPS, memory, heart.

Knowing even how my words often lie, slant lines with scant truth, I still seek words like dew in the desert to quench thirst.

Language - so much always remains unsaid. The holes allow us to recognize the world. Learn to lean on light in the darkness.

Moonshone stones like words rise up to the surface in a farmer's field, tugged by lunatic gravity, responding to the call.

Narrating my experience taxes the limits of language, leaves me in liminal spaces I will likely never traverse.

Order has an odour, even sometimes like ordure. The logic line is only one way. Try the ludic. For fun.

Phonse pronounced phonetic phrases with a parrot's panache and pissed poetic polyvalent possibilities outside the pot.

Question everything. What if? The world is transformed, even in the asking. What questions need to be asked?

Rhythmically, poems breathe, long heart's breaths full of the flowing, neverending geography, everywhere, always.

Sense runs both ways like the two strands of a reef knot, like shadows complement light in a counterpoint.

Today I saw a bumper sticker: Ban Leg Hold Traps, and I read: Ban Leggo Traps. My world sharply focused in my image alone.

Unlike undulating curves of oil in water, wind in snow banks, waves on a sandy beach, my handwriting does not flow and swirl.

Vases on window sills hold the poems I gathered for you in early autumn light.

Winnie the Pooh searches for the hole in order to find home. I search for the whole, too. Longing for the hole and home.

Xerographically language reproduces living, like chiaroscuro, in new conjunctions of light and dark.

Yarns yammer, yowl, yak, yelp, yawp, yell, full of yearning for you.

Zigzagging with the mark of Zorro, the poet begins with the end and ends in the beginning.

\author{
Poetry \\ slows us down, \\ calls us to play, \\ invites us to listen, \\ opens ways of knowing, \\ provides a site for dwelling.
}


"In a sense, as we are creative beings, our lives become our work of art" (Cameron \& Bryan, 1992, p. xvi).

\section{VERB}

I want to be a verb:

a word which

makes statements

gives commands

asks questions

too long I have been

written a noun only:

a name for a person

animal place thing

quality idea action

no longer satisfied

with being the name

the namer the named
I want to be a verb:

the naming

Carl Carls:

a word which

declares

authors

interrogates

I am I:

always be(com)ing endlessly mutable

subject in process

naming without end

$$
\begin{gathered}
\text { Poetry } \\
\text { slows us down, } \\
\text { calls us to play, } \\
\text { invites us to listen, } \\
\text { opens ways of knowing, } \\
\text { provides a site for dwelling. }
\end{gathered}
$$

"To invent a language is potentially to invent a world" (Rasula \& McCaffery, 1998, p. 49).

\section{$\mathrm{ZOO}$}

A with a sticky tongue the aardvark burrows in the earth for ants and termites like letters of the alphabet

B a bat uses echolocation to navigate dark, dense texts, interprets the lyricism of regnant resonant rippling lines

C a coyote composes its own lines in the cacti and sage, knows a language different from mine, insufficient for writing this poem

D in long walks near the slough, I hear ducks laughing, but I do not know their language, still content to ask, Why are the ducks laughing?

E with a phobia of worms and snakes, I especially screech when I see an eel draw its line in the brook, one more story I don't want

F with a fierce, feral resolve, I hunt truth with ferrets, hope to ferret truth out of its hiding places into the noon studded sun 
G according to Gary Larson the world offers daily both good gnus and bad gnus; of course, the alphabet is flexible

$\mathrm{H}$ the hen pecks at the hard scrabble backyard, finds pebbles and seeds like dry words that can sustain at least a lean narrative

I the still ibis is mostly a sculptor's image, but sometimes stumbles across the river and soars over the lettered landscape

J always a voyeur, the jealous jaguar watches from the parking lot of Tim Horton's, eats another donut, waits, prays for one more revelation

$\mathrm{K}$ a kangaroo jumps the endless expanse of the outback, and I too bounce too boisterously to know the steady place at the beginning of the alphabet

L just like no poet ever tames the wildness of language erupting with endless possibilities, nobody really tames a lion, its heart always hidden

M like most expository prose, the moose is big and slow, but occasionally startles

with an explosive burst out of the alders on the side of the highway as we pass

$\mathrm{N}$ the new-born newt knew no new news, but near a new moon ate fig newtons and dreamed a new-fangled newsreel about the New Age New Left in a New Deal

$\mathrm{O}$ with an ocelot's stealth we can walk in the spaces of the alphabet and leave no trace of our circuit on the catwalk

$\mathrm{P}$ it isn't true that I fear words, but I have learned to sneak up on them like porcupines before I steal their quills for more writing

Q like Dolly Parton the quetzal doesn't seem real, looks like a graphic designer's confection, challenges the alphabet to concoct new vocabulary

$\mathrm{R}$ my muddled imagination runs hypertextually in all directions, unlike the rhinoceros who always sees the sturdy singular point

S like a poet, the sloth has the good sense to linger in the spaces of the alphabet, refuses to hurry, knows the words will come

T Howard the Turtle's jokes didn't dazzle Al Hamel (unlike thigh master Suzanne Somers), groans only, but I always admired Howard's perseverance

$\mathrm{U}$ the unicorn is a creature that lives only in the untamed alphabet that can't stop with naming just the earth's millions of creatures

$\mathrm{V}$ I circle high overhead searching for the carrion left by others, a vicious avaricious vulture with claws too weak to chase vital verbs 
W like a whale in the ocean, scribing its shape in the ocean, while pressed on all sides by the ocean, I shape language, I am shaped by language

$\mathrm{X}$ the xerus stays close to the ground and plays its part in the Scrabble dictionary, assisting the player with the rich but notoriously difficult letter $\mathrm{X}$

$\mathrm{Y}$ the yak stands in a circle in the Arctic long night, silent, sure, knows enough letters huddled together will ward off the icicles of danger

$\mathrm{Z}$ the zebra exhibits sartorial splendor, black and white, like the alphabet, suitable for all occasions

$$
\begin{gathered}
\text { Poetry } \\
\text { slows us down, } \\
\text { calls us to play, } \\
\text { invites us to listen, } \\
\text { opens ways of knowing, } \\
\text { provides a site for dwelling. }
\end{gathered}
$$

"Evidence suggests that social communication is not rule-bound or subject to decree and regulation, but is consolidated in the ad hoc spirit of play" (Rasula \& McCaffery, 1998, pp. 49-50).

\section{CLICHÉ}

as luck would have it

I am a cliché

trite threadbare twice-told

tired but happy, tried but true

a banal bromidic bathetic

specimen of humanity

well-worn warmed-over worn-out

doomed to disappointment

shopworn stale stock

along these lines

I am a cliché

prosaic platitudinous

working like a Trojan

jejune vapid shallow

no bolt from the blue

common flat dull

at the parting of the ways

over-used used-up

all too soon

I am a cliché

hackneyed stereotypical

with method in my madness rubber stamped ready-made

safe and sound, sadder but wiser

derivative corny old hat

I set the wheels going

lifeless drained exhausted

still I was not always a cliché

once upon a time I was a word

repeated repeat repeated

repeat repeated repeat

once worth repetition

repetition rendered me worthless

the sprite turned trite

last as well as least

unable to keep up with the wor(l)d

as I grow older

always scribbled

I am more and more a cliché

my story more and more familiar

even before I have lived it

while less and less I write

my story written by others

too funny for words at least

a cliché in time saves nine 


\section{Poetry \\ slows us down, calls us to play, invites us to listen, opens ways of knowing, provides a site for dwelling.}

"A writer must resist the pressure of old formulae and work towards new combinations of language" (Winterson, 1995, p. 76).

\section{ANOTHER FAIRY TALE}

Once upon a time in school I was taught every sentence has a subject and a predicate verb, the backbone to which modifiers are attached, and ever since I have been on a journey

I am

a simple subject seeking modifiers a predicate verb seeking complements

Carl writes.

The sentence expresses a complete thought.

Is a thought ever complete?

Sad happy gentle angry generous selfish amorous cold honest deceitful wise stupid Carl writes.

Carl writes the story of his life quickly, eagerly, painfully, insightfully, slowly with little attention to truth or fairness.
Carl the subject and Carl the predicate are modified, complemented, expanded, but no more complete than Carl writes.

I was taught that a nominative absolute with a participle expressed or understood has the force of an adverb modifier, but has no grammatical connection with the rest of the sentence

I still don't know what a nominative absolute is but I feel like one-connected and not connected

Is writing all about writing myself to wholeness, seeking others to write me to wholeness, to modify me to completeness, a complete thought in a complete sentence, perhaps best to keep it simple: Carl writes.

$$
\begin{gathered}
\text { Poetry } \\
\text { slows us down, } \\
\text { calls us to play, } \\
\text { invites us to listen, } \\
\text { opens ways of knowing, } \\
\text { provides a site for dwelling. }
\end{gathered}
$$

"Poetic imagination is the last way left in which to challenge and conflict the dominant reality" (Brueggemann, 2001, p. 40). 


\section{SEE-SAW}

we are always jealous and upset that others have more even though most have far less we want the steak reflected in the mirror; it's bigger than the steak in our mouths we revel in a new Wal-Mart but are deaf and blind to revelation and revolution we pay lip service to emancipation but ignore emasculation and emaciation we desire what we can't have, and take little pleasure in what we have we celebrate a cult of celebrity when we need a culture of celebration we never meet an angel because we are always looking for an angle we will make the world safe by blowing up as much of it as we can we eat even if we aren't hungry; we eat but we are never satisfied we revel in reality shows where, in reality, reality never shows we are eating ourselves to death, frightened only by a diet we pursue trivial knowledge, but wisdom is in jeopardy we admire the momentary and ignore the momentous we mourn because we have to get up in the morning we laugh without joy and we weep without grief we seek an injection for rejection and dejection we pursue pleasure but no pursuit pleases us we are more erratic and neurotic than erotic we seek simulation but seldom stimulation we embrace infamy in the pursuit of fame we are impetuous but without impetus we want elation and get deflation we need hope but we mope we need amity but we sow enmity we are so apathetic we are pathetic we want flattery even if it flattens us we burn with desire but know little fire we admire eminence but love M \& M's we appreciate rigor and depreciate vigor we are stupidly astute and astutely stupid we fear the ambiguous like we fear bigamists we wine and dine, but mostly whine and pine we are motivated by exhibition without inhibition we stir up consternation instead of stirring conversation we claim to be God's but we don't know him or want to we are lost, awash and languishing in washed-up language we love gossip as long as we can gossip about somebody else we talk endlessly about the weather in order to drive silence away we live in pragmatic times with used paradigms, needy for paramedics we want small telephones and big SUV's, like our hearts and our desires we have more clothes than we can possibly wear but we always want more we know avarice is a vice, but it's still a nice vice full of vile and violent vitality we need a vantage point in order to see but we are always eager to take advantage we place our security in guns and devices for detecting guns and making bigger guns we ignore staring starving children but despair over a hole in a pair of favourite socks 


$$
\begin{gathered}
\text { Poetry } \\
\text { slows us down, } \\
\text { calls us to play, } \\
\text { invites us to listen, } \\
\text { opens ways of knowing, } \\
\text { provides a site for dwelling. }
\end{gathered}
$$

"My experience is not described or explained by language; it is language" (Griffin, 1995, p. 192).

\section{THIN SKIN}

I just wrote a good poem, a poem is an SOS scribbled to the world not this poem, another, a poem is a long slow run on the dike and called out to Lana, a poem is morning light in the harbour I just wrote a good poem, I said, a poem is a bloody nose but a nagging niggling voice, a poem is inscribing circles in the air for jumping through (not Lana's, always supportive) a poem is laughing with wild words resounded, your poems aren't any good, a poem is the dust on mistakes and while I don't really believe a poem is pizza and Girl Guide cookies my poems aren't any good, a poem is a gull in a gusty March storm I've been thinking a lot lately a poem is a yearning for the ineffable I can't just simply ignore a poem is the way words wind through the blood the dismissive judgements of others a poem is the late sun like cranberry claret (even though I want to and suspect I will) a poem is a call to read slowly as I have for a long long time, decades even, a poem is a sparrow in a bare alder branch by insisting my poems are good, a poem is a surprise party for words at least according to me (their value a poem is leaning into the wind to be known one distant day like a poem is the scent of aged whiskey Gertrude Stein knew the new poetry is a poem is a bouquet of calla lilies 
never appreciated for a long long time, a poem is these words, your words, more words, always words even a lifetime sometimes, even long a poem is a loud bump in another room after the poet's death), and Mother A.

a poem is a thousand snow geese rising from the slough said, you will never be a writer a poem is springing like Tigger and Lou said, your poems aren't very good a poem is a centipede with lots of feet with the kind of fundamentalist authority a poem is a gaggle of giggling geese and eagerness for strict categorization, a poem is transmuting the lead of experience into gold even hubris, only a teacher can muster, a poem is breath in an animated body and an external reviewer for my promotion a poem is standing knee-deep in mud said, his poems aren't very good,

a poem is four blackbirds in the snow on the backyard fence and I have been rejected by all

a poem is a heart grown still the pre-eminent literary journals a poem is these words lightly offered in Canada, and most of the less a poem is stillness in the flux eminent ones, too, and my last a poem is light leaning lightly with joyful dark royalty cheque still wasn't enough a poem is dark wine crushed at the back of your throat for a big pizza at Sorrento's, a poem is twelve grain bread brushed with olive oil and I can't find my poems a poem is a word that gives you goose-bumps in any bookstore in Corner Brook, a poem is the scent of rosemary lemon balm oregano and even in Deer Lake airport a poem is a sea that flows in you through me where I was sure my poetry was safe a poem is a cactus that seeks water in a desert from commentary and critique, a poem is the sun awash in a sea in summer's twilight Joe Mercer said, the first book is better a poem is a winter stone in April sun than the second (I should be glad Joe read both) a poem is the whispered response to prayer and I feel doomed that each 
a poem is the moon in winter's night subsequent publication (if ever a poem is a baby's smile without fear there are any more, so uncertain)

a poem is a tree afire in autumn's light will be worse than the last, a poem is scribbled letters, held in the wind and certainly never as good as the first, a poem is a crocus, purple and bold, in spring snow but in this cacophony of voices,

a poem is holding tentatively, instead of with tentacles

I wonder how my poems are being a poem is a sneeze in a crowded shopping mall judged (perhaps compared to Keats a poem is yearning and learning to listen and company, or perhaps compared a poem is January snow in a tall fir to an impressed gold standard of poetry a poem is a bucket of blueberries as if some king somewhere a poem is this moment, the moment of writing has measured the distance

a poem is singing in the lines, outside the lines from his nose to his toes and knows a poem is a meadow of wildflowers irrefutably a poem's goodness) a poem is the frost on a winter window and all I know is I must not a poem is a knock in the side of the head lose confidence in my poems a poem is rooted in the earth anymore than I will lose faith a poem is calling me calling you calling in my heart beaten but beating still a poem is waiting between the lines with hope and humour, held close, knowing a poem is a path in the frozen tundra of the heart well any poem, even mine, is better than none a poem is this heart's beat, beating heartfully in this poem

\author{
Poetry \\ slows us down, \\ calls us to play, \\ invites us to listen, \\ opens ways of knowing, \\ provides a site for dwelling.
}




\section{The Author}

Carl Leggo is a poet and associate professor in the Department of Language and Literacy Education at the University of British Columbia where he teaches courses in writing and narrative research. His poetry and fiction and scholarly essays have been published in many journals in North America and around the world. He is the author of two collections of poems, titled Growing Up Perpendicular on the Side of a Hill and View from My Mother's House (both published by Killick Press, St. John's), as well as a book about reading and teaching poetry, titled Teaching to Wonder: Responding to Poetry in the Secondary Classroom (Pacific Educational Press, Vancouver).

\section{References}

Brueggemann, W. (2001). The prophetic imagination (2nd ed.). Minneapolis, MN: Fortress Press.

Cameron, J., \& Bryan, M. (1992). The artist's way: A spiritual path to higher creativity. New York: G.P. Putnam's Sons.

Chang, J. (2003). Wild swans: Three daughters of China. New York: Touchstone.

Griffin, S. (1995). The eros of everyday life: Essays on ecology, gender and society. New York: Doubleday.

Mills, S. (1997). Discourse. London: Routledge.

Rasula, J., \& McCaffery, S. (Eds.). (1998). Imagining language: An anthology. Cambridge, MA: MIT Press.

Winterson, J. (1995). Art objects: Essays on ecstasy and effrontery. Toronto, ON: Knopf Canada. 